TITLE:

\title{
Genetic analysis of Nakano cataract and its modifier genes in mice.( Abstract_要旨 )
}

$\operatorname{AUTHOR}(\mathrm{S})$ :

Narita, Makiko

\section{CITATION:}

Narita, Makiko. Genetic analysis of Nakano cataract and its modifier genes in mice.. 京都 大学, 2002, 博士(医学)

ISSUE DATE:

2002-11-25

URL:

http://hdl.handle.net/2433/149358

RIGHT: 


\begin{tabular}{|c|c|}
\hline 氏 & 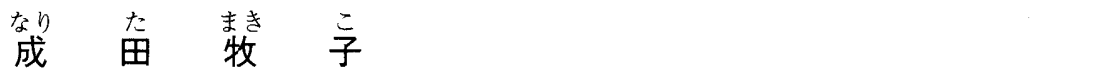 \\
\hline 学位(専攻分野) & 士（医 学） \\
\hline 学位記 番号 & 医 博 第 2532 号 \\
\hline 学位授与の日付 & 平成 14 年 11 月 25 日 \\
\hline 学位授与の要件 & 学 位規則 第 4 条第 1 項該当 \\
\hline 研究科・専攻 & 医学研究科病理系専攻 \\
\hline 学位論文題目 & $\begin{array}{l}\text { Genetic analysis of Nakano cataract and its modifier genes in mice } \\
\text { (Nakano マウスの遺伝解析と修飾遺伝子) }\end{array}$ \\
\hline
\end{tabular}

論文調査委員 教授鍋島陽一 教授本田孔士 教授日 合弘

\section{論文 内容 の 要旨}

Nakano cataract（NCT）マウスは1960年に中野らが発見した白内障を自然発症する常染色体劣性単一遺伝マウスである。 NCT の白内障発症については，内因性の Na, K-ATPase inhibitor により $\mathrm{Na}, \mathrm{K}$-ATPase 活性が減少することに起因す る osmotic cataractであること, Na, K-ATPase inhibitor は10kDaのペプチドであることがわかっているが，発症機構の 本質的な解明には至っていない。

NCT 原因遺伝子は NCT の congenic 系として確立された BALB/C - nct/nct と野生由来の近交系 Mus molossinus $(\mathrm{MSM} / \mathrm{Ms})$ とのバッククロス動物 BALB/C- nct/ nct $\times$ （BALB/c-nct/ nct $\times \mathrm{MSM} / \mathrm{Ms}$ ）を用いて第16染色体上 $38-43 \mathrm{cM}$ の位置にマップされた。本論文では $1 ， 000$ 頭のバッククロス動物を用いてさらに詳細にマッピングし，第16染色体上 D16Mit5 と D16Mitl85の間の 0.7cMの範囲に領域を狭めた。これはポジショナルクローニングで遺伝子を同定するため の重要な情報となる。

NCT マウスの白内障は生後 3 週にレンズ核が急激に白濁する pin-head type であるが, BALB/C-nct/nctは発症時期が 遅く，レンズの白濁も diffuse で緩慢である。BALB/C-nct/nct $\times(\mathrm{BALB} / \mathrm{C}-n c t / n c t \times \mathrm{MSM} / \mathrm{MS})$ のレンズを観察すると NCT マウスと同様の pin-head type と生後 5 - 6 週で発症する BALB/C- nct/ nct と同様の diffuse type が分離して出現し た。肉眼的に白内障を観察するまでの pin-head type と diffuse typeの病理組織像を比較すると, 両夕イプともbow 域レ ンズ上皮細胞核の残存, 赤道部でのレンズ上皮細胞の膨化・空胞, 前・後極部およびレンズ核周囲線維の変性がみられるが, pin-head type は生後 3 週から急激にレンズ核の濃縮・変性が進行し, diffuse type では核周囲, 前極, 後極部線維に限局 した変性が緩やかに進行する。SDS-PAGEでレンズタンパクを分析すると, BALB/c-nct/nctおよびバッククロスの白内 障レンズでは，正常および白内障発症以前のレンズではみられない $26 \mathrm{kDa}$ および $20 \mathrm{k} \mathrm{Da}$ 以下の水溶性タンパクが出現し, $29 \mathrm{kDa}$ の水溶性タンパクが消失していた。これは pin-head type, diffuse type とも同様で, クリスタリンの分解によるも のと考えられた。

NCT の白内障病型 subtype はほ st modifier geneによると考えられ, バッククロス動物の 2 つの subtype の分離比から 修飾遺伝子は複数であることが推察された。pin-head type, diffuse type それぞれ50頭を用い, マイクロサテライトマーカ ーでスクリーニングした結果，D3Mit12 と D3Mit41で $\chi^{2}$ 值 $13.1\left(\mathrm{P}=2.9 \times 10^{-4}\right)$, D1OMit151 で $\chi^{2}$ 值 $8.3(\mathrm{P}=3.9 \times$ $10^{-3}$ ) を示した。D3Mit12 とD3Mit41の間にはNa, K-ATPase $\alpha$ subunit と gap junctionの構成成分である Gja8 Gja5，D1OMit151 近傍にはレンズタンパクの MIP26 が存在する。

\section{論 文 審査 の 結 果 の 要 旨}

Nakano cataract（NCT）マウスは常染色体劣性単一遺伝による白内障ミュータントである。内因性の抑制ペプチドの形 成により $\mathrm{Na}, \mathrm{K}$-ATPase 活性低下をきたす osmotic cataract と推定されている。申請者はNCTのコンジェニック系 
$\mathrm{BALB} / \mathrm{c}-n c t / n c t$ マウスと $\mathrm{MSM} / \mathrm{Ms}$ 系との1000頭の戻し交配系を遺伝解析し，責任遺伝子の所在を第16染色体上で D16Mit5 とD16Mit185の間の $0.7 \mathrm{cM}$ の領域に狭めた。

Nakano マウスの白内障はレンズ核が急激に白濁する pin-head typeであるが, BALB/c-nct/nctでは発症時期が遅く， 緩慢な核周囲皮質線維の変性による diffuse typeである。戻し交配系ではこの両型が分離して出現した。戻し交配世代の解 析からこのようなサブタイプの分離に与る 2 つの modifier 遺伝子を第 3 ，第10染色体にそれぞれマップした。

以上の研究はレンズの透明性保持の分子生物学的理解に貢献するものである。従って, 本論文は博士 (医学) の学位論文 として価值あるものと認める。な扮，本学位申請者は，平成14年10月16日実施の論文内容とそれに関連した試問を受け，合 格と認められたものである。 